\title{
REGULATORY COMPETITION IN FOCUS
}

\author{
Daniel C. Esty*
}

One of the central issues in recent regulatory reform debates has been the question of whether government regulation should be undertaken at centralized or more decentralized levels. In the United States, 'new federalists' argue for a broad return of regulatory authority to the states and even to the local governments. Newt Gingrich argues: 'We must replace our centralized, micromanaged, Washington-based bureaucracy with a dramatically decentralized system more appropriate to a continent-wide country ... closer is better should be the rule of thumb. ${ }^{1}$ A number of academics have joined this debate with scholarly arguments to support the call for decentralized governance processes. Ricky Revesz, for example, suggests that not only does geographic diversity argue for decentralized regulatory approaches, but that a set of horizontally arrayed jurisdictions competing in the regulatory realm - creating, in effect, a market in 'locational rights' - will produce enhanced social welfare. ${ }^{2}$

But while a whole field of academic literature has emerged from Charles Tiebout's seminal 1956 article positing the benefits of regulatory competition, ${ }^{3}$ others have worried that inter-jurisdictional competition could trigger a welfare-reducing 'race toward the bottom' in standard setting. ${ }^{4}$ Still others have concluded that the results of regulatory competition are likely to be highly sensitive to context and that the conditions under which regulatory competition will generate welfare gains might be quite limited. ${ }^{5}$

* Associate Dean, Yale School of Forestry and Environmental Studies and Director, Yale Center for Environmental Law and Policy. Correspondence address: Yale Law School, PO Box 208215, New Haven, CT 06520-8215, USA. Email: daniel.esty@yale.edu.

' Newt Gingrich, Contract to Renew America 9 (1995).

${ }^{2}$ Richard L. Revesz, "Rehabilitating Interstate Competition: Rethinking the "Race to the Bottom" Rationale for Federal Environmental Regulation', 67 NYU L Rev 1210 (1992).

${ }^{3}$ Charles M. Tiebout, 'A Pure Theory of Local Expenditures', 64 J Pol Econ 416 (1956); see also William A. Fishel, 'Fiscal and Environmental Considerations in the Location of Firms in Suburban Communities', in Edwin S. Mills and Wallace E. Oates (eds), Fiscal Zoning and Land Use Controls 119 (1975); Wallace E. Oates and Robert M. Schwab, 'Economic Competition Among Jurisdictions: Efficacy Enhancing or Distortion Inducing', 35 J Pub Econ 333 (1988).

${ }^{4}$ See Richard B. Stewart, 'Pyramids of Sacrifice?: Problems of Federalism in Mandating State Implementation of National Environmental Policy', 86 Yale LJ 1196, 1210-20 (1977); see also Ross Perot's memorable worries about a 'giant sucking sound' as US factories and jobs moved to Mexico, drawn by more lax regulatory standards, in Ross Perot, Save Your Job, Save Our Country 41 (1993).

'See, e.g., Alvin K. Klevorick, 'Reflections on the Race to the Bottom' in Jagdish Bhagwati and Robert Hudec (eds), Fair Trade and Harmonization: Prerequisites for Free Trade? 459 (1996); Daniel C. Esty, 'Revitalizing Environmental Federalism', 95 Mich L R 570 (1996). 
How widespread are the gains from regulatory competition likely to be? When will harmonization of standards produce better results? These issues have generated a raging debate in US academic circles. While Revesz places his argument in the environmental context, other scholars suggest that regulatory competition might improve social welfare in a range of regulatory domains. Notably, Ralph Winter and Roberta Romano argue in favor of interstate competition in the corporate law domain. ${ }^{6}$ Henry Butler and Jon Macey observe that such gains might be obtained in the banking field but only if federal deposit insurance does not create an economic externality by creating an incentive for higher risk tolerance among state regulators who know that any bank that fails will be bailed out by the national FDIC guarantees. ${ }^{7}$

Similar debates are going full-bore within the European Union around the concept of 'subsidiarity'. After several decades of growing centralization of regulatory authority in Brussels and the issuance of hundreds of EU-wide 'directives' that seek to harmonize standards across the European Union, critics are casting doubt on the benefits of this movement toward uniformity. ${ }^{8}$ Indeed, the EU's response to divergent regulatory standards clearly draws on the logic of the trade realm where such differences are perceived as a potential basis for unfair competitive advantage and perhaps even decried as "beggar thy neighbor' policies.

The debate over whether some form of harmonization or convergence of standards produces superior results by mitigating the risk of a race toward the bottom in regulatory standard setting or whether regulatory competition will generate pressures that will be welfare-enhancing has now spilled over into the global realm as the World Trade Organization (WTO) attempts to sort out the rules of behavior for international commerce. Calls for common labor, environment, tax, and antitrust (competition) standards are growing. Where inter-jurisdictional externalities exist (e.g. transboundary pollution spillovers), a strong consensus backs the need for overarching common rules. But where no such spillovers are present, the argument for regulatory diversity seems much stronger. Nevertheless, there remains a high degree of confusion and disagreement as to these points.

Believing that the 'regulatory competition versus harmonization of standards' debate would benefit from more solid analytic underpinnings, the Yale Law School and University of Liege Center for European Legal Studies organized a workshop in New Haven, Connecticut, in October 1999.

- See Ralph K. Winter, Jr, 'Shareholder Protection and the Theory of the Corporation', $6 \mathrm{~J}$ Legal Stud 251, 261-73 (1977); Roberta Romano, 'Law as a Product: Some Pieces of the Corporation Puzzle', $1 \mathrm{~J} \mathrm{~L} \mathrm{Econ} \mathrm{\&} \mathrm{Org} 225$ (1985).

${ }^{7}$ See Henry N. Butler and Jonathan R. Macey, 'The Myth of Competition in the Dual Banking System', 73 Cornell L Rev 677, 713 (1988).

B See Daniel C. Esty and Damien Geradin, 'Environmental Protection and International Competitiveness: A Conceptual Framework', 32 J World Trade 5 (1998) (arguing that 'harmonization' of standards need not result in uniformity). 
Drawing scholars from both sides of the Atlantic, the workshop examined the social welfare implications of regulatory competition comparatively across: (1) regulatory areas (environment, banking, corporate law, labor, tax, antitrust); (2) models of economic integration (from highly integrated systems, such as the United States to somewhat less integrated systems such as the European Union, to loosely integrated regimes such as the WTO); and (3) disciplinary perspectives (law, economics, business, and political science). The workshop sought to sharpen thinking about the circumstances that would likely yield gains from regulatory competition and to contrast these cases with others where heightened cooperation in standard setting or broader regulatory harmonization might increase social welfare.

A consensus seems to have emerged in support of the hypothesis that benefits from regulatory competition are highly context specific - making the comparative analysis especially illuminating. The full range of papers spelling out when and where these benefits are likely to be found will be published late in the year 2000 in an Oxford University Press volume tentatively titled Regulatory Competition and Economic Integration (Daniel C. Esty and Damien Geradin, eds). We have selected, however, a few of the key papers that highlight the critical issues to publish in advance in this issue of the fournal of International Economic Law. 
HeinOnline -- 3 J. Int'l Econ. L. 2152000 